\title{
Digital tools for improving teenager's speaking
}

\section{Herramientas digitales para mejorar la producción oral de los adolescentes Sara Merino-Munive ${ }^{a}$, Rocio Barbosa-Trujillo ${ }^{b}$ Leticia Estudillo-León $^{c}$}

\begin{abstract}
:
In EFL classes, Mexican teenagers often face problems when trying to communicate orally in English. Martin and Molina (2011) argue that “...not knowing how to speak effectively limits severely our career possibilities and personal” (p.92). The present paper reports on a study of the impact of incorporating different online resources to improve adolescents' speaking in English through an exploration of students' perceptions regarding their use, as part of an extracurricular English language course at a Mexican public secondary school.

Students recorded themselves once a week using specific online tools for their homework. The main purpose was to give students the opportunity to record and hear themselves as many times as necessary until they considered their work was acceptable. Additionally, they were aware of being listened by their teacher and classmates. Results seem to suggest that students' self-confidence when speaking in the classroom, motivation to speak and awareness of features of acceptable speech were enhanced by using these online tools to practice speaking independently.
\end{abstract}

\section{Keywords:}

EFL, ICT, speaking, motivation, teenagers

\section{Resumen:}

En las clases de inglés como lengua extranjera, los adolescentes enfrentan problemas cuando intentan comunicarse oralmente. Martin and Molina (2011) argumentan que" el no saber cómo hablar efectivamente limita severamente nuestras posibilidades de carrera y personales" (pág. 92). Partiendo de esta premisa, el presente trabajo se enfoca en incorporar diferentes recursos en línea para mejorar la producción oral en inglés de los adolescentes.

Esta investigación explora las percepciones de los estudiantes cuando usaron herramientas en línea para practicar la producción oral. Como tarea los estudiantes se grabaron así mismos una vez por semana usando herramientas en línea. El propósito principal fue brindar a los alumnos la oportunidad de grabarse y escucharse a ellos mismos tantas veces como lo necesitaran hasta que estimaran que su trabajo era aceptable. Además de que ellos estaban conscientes de que serían escuchados por el profesor y sus compañeros. Los resultados muestran: seguridad cuando los alumnos hablan en el salón, motivación cuando usan herramientas en línea para practicar la producción oral y estar conscientes de las características de un discurso aceptable.

\section{Palabras Clave:}

EFL, TICs, producción oral, motivación, adolescentes

\footnotetext{
a Sara Merino-Munive, Universidad Autónoma de Puebla, https://orcid.org/0000-0001-8295-3136, Email: sara.merino@correo.buap.mx ${ }^{b}$ Rocio Barbosa-Trujillo, Universidad Autónoma de Puebla, https://orcid.org/0000-0001-5708-0134, Email: rocio.barbosa@correo.buap.mx 'Leticia Estudillo-León, Universidad Autónoma de Puebla, https://orcid.org/0000-0003-4808-5368, Email:
} leticia.estudillo@correo.buap.mx 


\section{INTRODUCTION}

In Mexican EFL classrooms, teenagers often seem to face problems when trying to communicate orally. Martin and Molina (2011) sustains that: “...not knowing how to speak effectively limits severely our career possibilities and personal" (p. 92). The present paper reports on a study of the impact of incorporating different online resources to improve adolescents' speaking in English as a Foreign Language (FL) through an exploration of students' perceptions regarding their use in an extracurricular course at a Mexican public high school. This project explores students' perceptions while using and after using specific online tools to practice speaking.

Students recorded themselves once a week for homework, using the online tools Vocaroo and VoiceThread. The main purpose was to give students the opportunity to hear and record themselves as many times as necessary until they considered their work was acceptable. Moreover, students were aware that their recordings would be listened to and assessed by their language teacher and peers. One research question guides this project: What are students' perceptions concerning the use of specific online tools to improve their speaking skills? Our findings seem to suggest that students' self-confidence when speaking in the classroom, motivation to speak and awareness of features of acceptable speech were en hanced by using these online tools to practice speaking independently.

\section{LITERATURE REVIEW}

According to Yunus (2007), during the past 20 years, the use of Information Communication Technologies (ICT) has been considerably increased in almost all language classrooms. The use of ICT has different purposes; among others it is usually helpful to provide extra material, support daily face-to-face classes in order to help students understand and practice new language and independent learning skills. Furthermore, the internet provides an extensive number of resources and materials to support the language learning process, such as readings, blogs, interactive webpages, games, among others, which are commonly free. In the same vein, Moya (2013) says that ICTs is a collection of different technologies which have been developed to be used by people for their benefit because ICTs are intended to help, to support, to be accessed and organized by users; in this light, the use of ICTs also implies learning how to use them and in which contexts. That is the reason why EFL teachers face an online challenge in which they need to know how to help learners become more selfdirected and collaborative with peers than they might have been in earlier, now outdated courses (Conrad \& Donald son, 2004)

The growth of technology has transformed the way education is delivered: its presence has led to a huge shift in different aspects of teaching, learning and assessment in the classrooms in the past two decades. In English language teaching in Mexican state universities, it has been becoming increasingly common to see teachers using ICTs in their lessons. At this moment, it seems to be "natural" for some Mexican English teachers and students to incorporate the use of ICT in a language lesson to reinforce and increase the effectiveness of the learning process. Moya (2013) suggests that the selection of ICTs to support the process of learning a language should be based on students' needs, pertinence, and accessibility. Therefore, with the endless resources found on the net, English Language teachers can select the most appropriate ones to engage students' attention and make a difference in their learning after carrying out a thorough needs analysis. And this is since technology can be used to help students improve their language learning, in this case English, with authentic and motivating resources from the net. Cakici (2016) also argues in favor of implementing the use of ICTs because they produce a change in the language learning environment, specifically to motivate students and increase consciousness of features of the foreign language. Moreover, the author mentions that using ICT in the foreign language classroom reduces students' anxiety and encourages them to take the risk to practice outside the classroom. Jayanthi and Kumar (2016 cited in Cakici, 2016) sustain that ICTs in the English class have a positive impact in terms of availability of materials, students' attitudes, learner autonomy, authenticity, helping teachers, student-centered, and self-assessment.

In the digital era, teenagers seem to be, usually, better ICT users than parents and teachers; however, it is not always the case, thus it is necessary to bear in mind that teachers should be able to support students to manage software/hardware, Apps and any other kind of resource to be used, otherwise the functionality of the extra net resources can fail (Cakici, 2016). In this respect, it is of vital importance that teachers create or look for strategies that could help language learners handle challenges so they feel more relaxed when it comes the time of producing in the target language. On occasions, learners need to be encouraged to practice speaking in English, engage in real-life communication activities and meaningful tasks in which they express themselves in a more natural conversation setting. In other words, the knowledge and expertise of the teacher are essential in the creation of and/or assignment of ICT-based activities to engage students, effectively combining ICT tools with sound instructional practices and activities, for effective learning outcomes (Arús \& Rodriguez, 2014).

For this reason, in the English Language Teaching field, technology can have a great impact, due to the fact that it provides students the opportunity to practice all language skills (Mahmoud \& Abdelsalam, 2016). Besides that, a virtual learning environment can make students feel less anxious about speaking about certain topics, hence they can produce the 
language without feeling the pressure of being in front of an audience.

In the light of current views on the effectiveness of combining sound pedagogy with ICT to enhance language learning and intending to contribute to the field, we selected two such tools, VoiceThread and Vocaroo, with the aim of exploring the ways in which these two digital tools seem to benefit teenage English language learners in a particular Mexican language learning context, by providing them with opportunities to develop and enhance their speaking skills, increase their participation and build their confidence when producing output in the target language.

\section{VOICETHREAD}

VoiceThread is an online tool that has received positive feedback when used in academic contexts, from both teachers and learners, due to its ability to help convey a feeling of social presence in online learning (Delmas, 2017). VoiceThread enables users to upload comments in an audio version and includes a narrating tool as well as a web-cam to encourage online discussion of media artifacts, which can be images, presentations or videos. One important advantage of VoiceThread is its utility to enable students and teachers to share their voices in an online learning environment and enhance the understanding of nuances expressed through voice (Pacansky-Brock 2014). Kent (2017) further suggests that VoiceThread is adaptable to different types of second language learning contexts and learner profiles. This implies that any EFL teacher can take advantage of VoiceThread. Furthermore, it can be employed to develop critical thinking along with communication skills of learners. In addition, Pires (2010) explains there is a wide variety of activities EFL educators have developed using VoiceThread, such as discussion, anecdotes, problem-solving tasks and peer review among others (as cited in Kent, 2017, p.4), to help students work collaboratively.

\section{VOCAROO}

Vocaroo is a free online recording tool which allows users to record their voice and create audio files. These voice files can then be shared with other people, in this case, students and teachers, by sending a link or embedding code on a website. Voice recordings have also been used in language teaching to nurture students speaking skill. Moreover, EFL teachers can use Vocaroo to digitally record audio descriptions of QR codes used in different activities, which makes this tool adaptable to the needs of the teacher. In addition, this tool is accessible at no expense, a special feature that makes it especially accessible (Charles \& Dickens, 2012). There is little research about using Vocaroo as a means of improving students' speaking skill. Hence, this research may contribute to provide more information on how Vocaroo can be used as one of the Apps to encourage self-evaluation on new knowledge and give them language learning autonomy in developing their speaking skills; an example on how online tools help to improve significantly students ' oral proficiency is provided in the study by $\operatorname{Kim}(2014)$.

\section{METHODOLOGY}

The present research was carried out using a mixed methods approach, combining qualitative and quantitative approaches in the design of a piece of research. Creswell (2018) defines qualitative research as the following "it begins with the assumption and the use of an interpretative/theoretical framework that informs the study of research problems, addressing the meaning individuals or groups ascribe to a social or human problem" (p. 8). Additionally, Creswell (2002) states that "In quantitative research, the investigator identifies a research problem based on trends in the field or on the need to explain why something occurs" (p.13). In line with the former, this research focuses on finding out more about the usefulness of two Apps, Voicethread and Vocaroo to evaluate how students perceive their use.

The results relating to student perceptions regarding the helpfulness of vocaroo.com and voicethread.com were derived by analyzing data collected by means of a questionnaire with nominal scale questions as Creswell recommends (2018). The questionnaire consisted of a series of open-ended questions and was distributed to the participants using an online format. Participants were asked to share their experiences on using the mentioned Apps to practice listening and speaking skills. The questionnaire was conducted in English, because it would help students to practice the foreign language in a different context. For the present research, the results were focused on students' responses to the questionnaire. All participants had spent one year studying English as an extracurricular class when the research was carried out.

The overarching research question was: What are students' perceptions about using VoiceThread and Vocaroo to improve their speaking skills?

With regard to the research context, the study was implemented in a two-year, extracurricular English course. The main purpose of this course is to provide secondary school pupils the opportunity to study English in a different context from their curricular classes, with the aim of achieving at least a B1 according to the Common European Framework of Reference (CEFR) at the end of the two years. Students were fourteen and fifteen years old when the research was carried out. The participants of the research were sixteen volunteer students. Parents provided their consent for their children to participate in different activities which included recording their voices by using the apps (Vocaroo and VoiceThread) as well as 
taking part in this research. It is important to mention that the consent letter was signed by parents at the very beginning of the course. All of them were enrolled in public secondary schools and did not have previous formal instruction in English. During the classes, students were immersed in a range of different activities to help them improve their English. However, this research focused specifically on exploring how VoiceThread and Vocaroo helped students, according to their own perceptions, to improve their speaking in English.

English language was presented to the students in diverse manners using a text book, games, extracurricular activities, videos, songs and of course using online tools. From the beginning of the course, students seemed to experience some kinds of barriers when they were required to speak in the classroom. For this reason, we became interested in using different activities, especially online tools, to motivate students to practice and improve their speaking outside the classroom. Through the use of these online tools, students were able to practice speaking in their own time.

Six activities were designed, based on different topics, to correspond with each of the six different units of the book. Three involved using Vocaroo.com and the other three required the use of VoiceThread.com. As mentioned above, both of these tools are free and are designed to enable users to record and exchange audio recordings. The tool Vocaroo.com is a free online voice recorder and VoiceThread.com is a learning tool for enhancing student engagement and online presence where they can record their voices, create video, send a different file or write a contribution (Indiana University, 2019).

For this project, students were asked to do three Vocaroo recordings and send them to the teacher. Another set of three activities were carried out by sharing ideas using Voicethread.com; in these activities, students had to follow the instructions of the teacher. Learners needed to record themselves, but this time they knew in advance that they would also be heard by their classmates. They used the topics of each unit as a basis for the speaking activity, thus students had already worked on the background of the grammar, vocabulary and the activities done in classes. The last activities using voicethread.com (Figure 1) had a different purpose, since in this one, students were asked to share which their favourite type of learning activity had been, during the English program, such as: in class activity, a museum visit, a teamwork activity, a celebration, among others. Figure 1 shows the last VoiceThread activity, for which the teacher wrote the instructions and students recorded their responses.

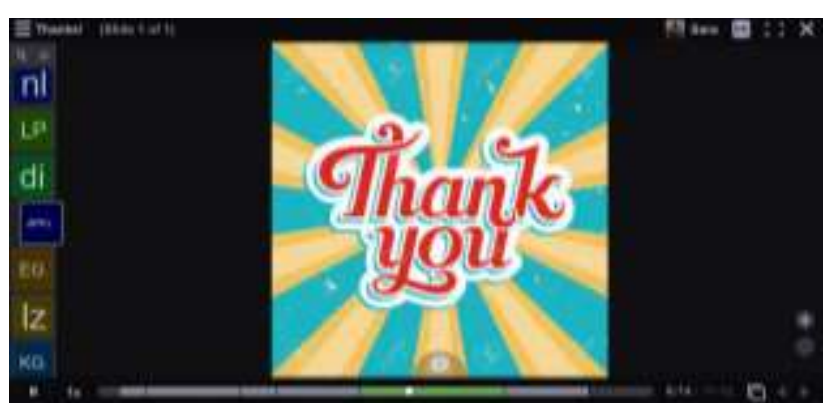

Figure 1: Students using VoiceThread.com in the last activity.

\section{RESULTS}

After practicing speaking using the online resources, students answered the online questionnaire on Google Drive. The aim of using an online questionnaire was to identify the students' perceptions about using vocaroo.com and voicethread.com to practice and improve the foreign language, specifically to gain self-confidence to speak.

The questions (Appendix 1) were designed to identify the areas where students thought they needed to work more on and how they believed that the use of online tools had helped them to improve their speaking and listening skills. The last part was to focus on whether they would like to continue using online tools to improve their foreign language skills.

In the first section of the questionnaire, students selected the areas where they considered themselves to be having more problems; they could select more than one option. Figure 2, shows that speaking obtained the highest score, with 12 answers, then listening, with 11 answers and after that, vocabulary, with 8 answers. The rest of the areas where students considered that they had problems were: grammar (4), reading (2) and writing (2). Based on the previous results, this research had focused on activities that help students to improve speaking skill, and the decision seems to have been appropriate, since the students themselves identified that listening and speaking were the two areas they most needed to work on.

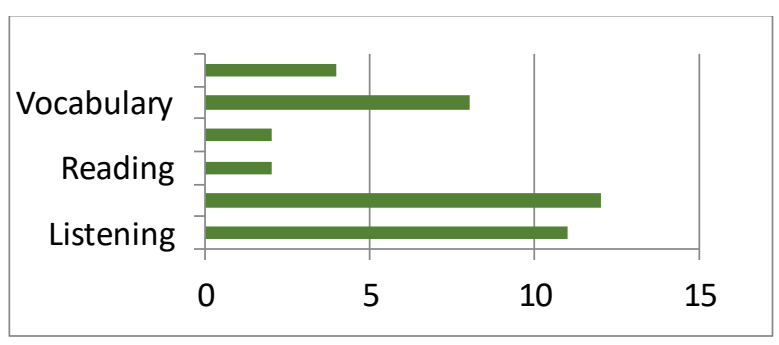

Figure 2: Challenging skills

With regard to speaking, according to students' answers, they mentioned that they needed to work on speaking more than any other skill. However, they also expressed that they felt nervous when they speak in English. The purpose of this section was to identify whether students felt nervous, good 
or confident when practicing speaking. Figure 3 shows students feelings about speaking. Eight students mentioned that they felt nervous when they practice speaking, six students mentioned they felt good when practicing speaking and two students needed more practice in this area. However, none of the participants expressed confidence when practicing speaking. These results were significant as it can be seen that nervousness could be the biggest barrier when speaking in English. Besides that, nervousness does not mean that students did not know the language or have the elements for developing a conversation; it could indicate a lack of practice. Thus, through the use of online tools students should be benefited, considering that as much as they practice and feel confident as much as they avoid being nervous.

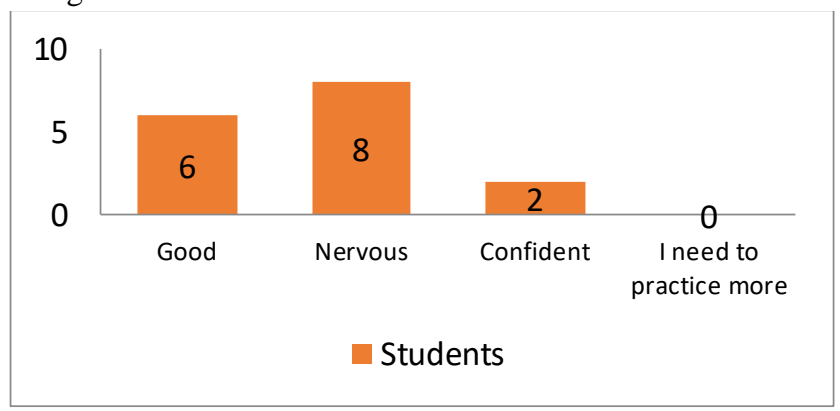

Figure 3: Feelings when practicing speaking.

Students seemed to be conscious of the need to practice their speaking more. In the light of this, it was important to explore in which context they felt better when practicing speaking. Figure 4 shows the results of students' feelings when practicing speaking in the classroom. Students mentioned that seven of them felt better when practicing speaking in the classroom. This indicates that they like to participate in classes, do different activities such as oral presentations, dialogs, roleplays and other kind of speaking activities; as they used to do in the classroom. On the other hand, nine (the majority) of the students mentioned that they felt better when practicing English by themselves. This relates directly to the focus and main interest of the present study, which is providing students with a space where they can practice speaking skills outside the classroom, using two specific online tools.

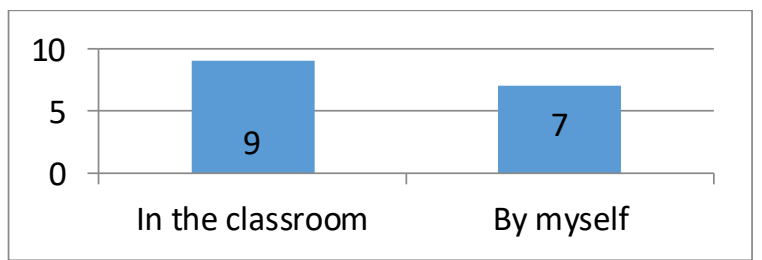

Figure 4: Feelings when practicing speaking in the classroom or by myself

Students were then asked whether or not they liked using the internet to practice English. The responses were limited to "yes" and "no", but enriched with explanations. The minority of the students answered that they did not like practicing English using online tools; the main reason was that they considered the internet to be useless and they got confused. On the contrary, the majority of the students agreed with the positive benefit they could obtain when using the internet to practice English. Some of the reasons were: they could find more exercises on the internet; they could find different material such as videos and readings in English. One student mentioned, "I see and hear how it is pronounced"; in this light, students noted that they could practice vocabulary and pronunciation using resources on the internet, all these to reinforce their learning. (See Table 1)

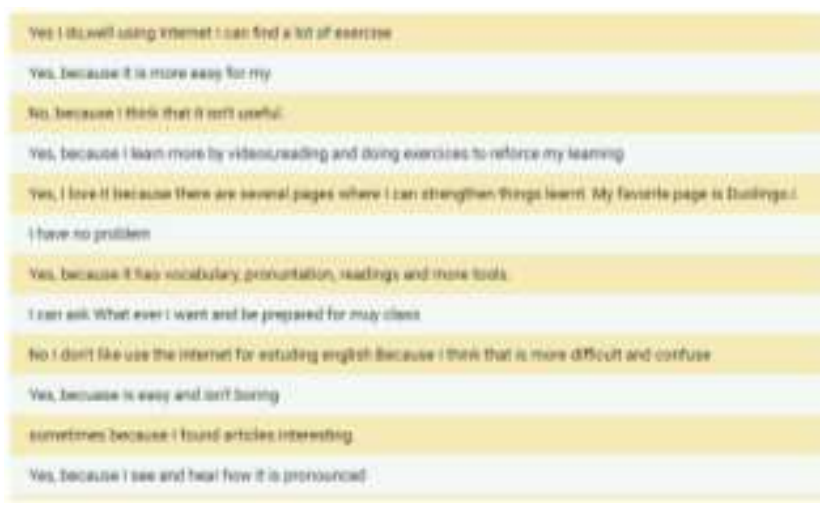

Table 1: Students likes and dislikes with regard to using online tools to practice English.

The main objective of the current research was to explore students' perceptions regarding using online tools to improve speaking; therefore, after practicing with two different online tools, students were asked to share their experiences. Figure 5 shows that ten of the students said that their experience was "Good" when using the internet to practice English, four of the students considered that their experience was "Excellent", two students mentioned it was "Nice"; no one mentioned that it was not a good experience. As a result, it seemed that all of the students had a positive experience when using VoiceThread and Vocaroo to practice English online. The perceptions probably range from "Excellent" to "Good", because of their technological abilities or familiarization with the tools. However, this assumption would need to be investigated further to establish any claims.

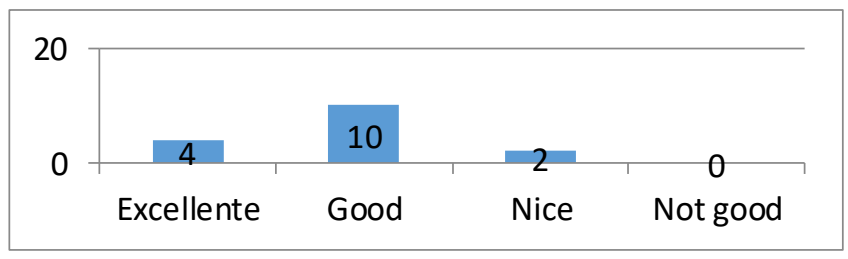

Figure 5: Experiences using the internet to practice English 


\section{CONCLUSIONS}

In the present project, the main intention was to explore secondary school students' perceptions after using two online tools to practice their speaking in their own time, outside the classroom. The results show that students seemed to enjoy practicing speaking in the foreign language, in this case, English, using VoiceThread and Vocaroo. During the different activities, students expressed that they were having positive experiences, they expressed themselves orally during the class and they had a positive attitude toward using online tools to improve their spoken English. However, students mentioned that they felt nervous speaking and preferred to practice speaking in the classroom, they have a good experience working with online tools; moreover, they would like to continue using online tools in their foreign language learning process.

In general, students had positive experiences using online tools to practice speaking English. It is important to highlight that students received instruction regarding how to use the online tools before being left to use them independently, and they were a very participative group in general. Students' performance in the different recordings showed improvement in fluency and pronunciation. In the light of this, it would seem to be the case that these students felt more secure to speak in the classroom before doing the third online activity. However, they said that they need the teacher's help and support to practice speaking. This reaction could be because they were still rather young to take the speaking process as their own responsibility. Besides that, this was a good example for them of how to become more autonomous learners and use online tools to help them improve their speaking in English.

\section{REFERENCES}

[1] Arús J., \& Rodriguez P. (2014) Autonomous learning resources for

ELT: What learners think Encuentro 23, 2014,pp. 1-15

[2]Cakici, D. (2016). The use of ICT in teaching English as a foreign language. Retrieved from Participatory EducationalResearch (PER), 73-77. Retrieved from https://www.researchgate.net/publication/322294214_The_use_of_IC T_in_teaching_English_as_a_foreign_language

[3]Charles, K.J., \& Dickens, V. (2012). Closing the

Communication Gap. Teaching ExceptionalChildren, 45 (2), 24-32

[4]Conrad, R., \& Donaldson, J. (2004). Engaging the online learner:

Activities and resources for creative instruction. San Francisco, Calif.: Jossey-Bass

[5]Creswell, J. W. (2002). Educational research: Planning, conducting,

and evaluating quantitative. (4th Edition). Pearson
[6]Creswell, J. W., \& Poth, C. N. (2018). Qualitative inquiry and research

design: Choosing among five approaches. (5th Edition). Sage publications.

[7]Delmas, P.M. (2017). Using VoiceThread to create community in online learning. TechTrends, 61, 595-602.

[8]Indiana University (2019). Retrieved from: https://kb.iu.edu/d/bduw

[9]Izquierdo, J., de-la-Cruz-Villegas, V., Aquino-Zúñiga, S. P., Sandoval-

Caraveo,M. D. C., \& García-Martínez,V. (2017). Teachers' use of ICTs in public language education: Evidence from second language secondary-schoolclassrooms. Comunicar, 25(50), 33-41.

[10]Kent, D., (2017). Constructing Visually-Based Digital Conversations

in EFL with VoiceThread. Teaching English with Technology, 17 (1), 3-16.

[11]Kim, S. H. (2014). Developing autonomous learning for oral

proficiency using digital storytelling. Language Learning \&

Technology 18 (2), 20-35. Retrieved from

http://llt.msu.edu/issues/june2014/action1.pdf

[12]Mahmoud, N. and Abdelsalam, H. (2016). Using Voice Thread to

Develop EFL Pre-service Teachers' Speaking Skills. International Journal of English Language Teaching, 4(6), 13-31. Retrieved from http://www.eajournals.org/wp-content/uploads/Using-Voice-Threadto-Develop-EFL-Pre-Service-Teachers-Speaking-Skills

[13]Martin, A and Molina, M. (2011) The Use of ICTs to Improve

Communicative Skills in a Bilingual Context: an Educational Project of the Spanish Ministry of Education in Melilla, ICTLL (4th Edition). Pixel

[14]Moya, M. (2013). De las TICs a las TACs: la importancia de crear

contenidos educativos digitales. DIM: Didáctica, Innovación y Multimedia, (27), 1-15.

[15]Pacansky-Brock, M. (2014). Learning out loud: Increasing voluntary

voice comments in online classes. In P. Lowenthal, C. York, \& J. Richardson (Eds.), Online learning: Common misconceptions, benefits and challenges (pp. 99-114). New York: Nova Science Publishers

[16]Yunus, M. (2007). Malaysian ESL teachers' use of ICT in their classrooms: expectations and realities. ReCALL, 19(1), 79-95. 
Appendix 1

Questionnaire for students

1. How old are you?

$\begin{array}{ll}\text { a) } 14 \text { years old } & \text { b) } 15 \text { years old }\end{array}$

2. In English I am good at:

a)listening b)speaking c) reading d)writing e)grammar

f)vocabulary

3. In English I need to work at:

a)listening b)speaking c) reading d)writing e)grammar

f)vocabulary

4. I like to practice English:

a)in the classroom b)using internet c) at home

5. When I practice Speaking I feel:

a)good b) nervous c) confident d) I need more practice

6. I feel better if I practice Speaking:

a) In the classroom b) by myself

7. I feel better if I practice Speaking in the classroom because:

8. I feel better if I practice Speaking by myself because:

9. Do you like to use internet to practice English? if so, Why? Explain

10. Do you like to hear your classmates to practice speaking? a)yes b)no

11. How was your experience using internet to practice English? a) Excellent b) good c)nice d)not good

12. Would you like to continue using internet to practice English? a) Yes b) no 